\title{
SHARP INTEGRAL INEQUALITIES FOR C-MONOTONE FUNCTIONS OF SEVERAL VARIABLES
}

\author{
IVAN PERIĆ, LARS-ERIK PERSSON AND ANNA WEDESTIG
}

Abstract. Some sharp integral inequalities for C-monotone functions of several variables are proved. All cases of equality are found and some related results are pointed out and discussed.

Mathematics subject classification (1991): 26D15, $26 \mathrm{D} 07$.

Key words and phrases: Inequalities, integral inequalities, multidimensional, C-monotone functions, best constants, sharpness.

\section{REFERENCES}

[1] S. BARZA, J. PeCARIC AND L. E. PersSON, Reversed Hölder inequalities for monotone functions of several variables, Math. Nachr. 186 (1997), 67-80.

[2] J. Bergh, V. I. BuRENKov AND L. E. PersSon, Best constants in reversed Hardy's inequalities for quasimonotone functions, Acta Sci. Math. (Szeged) 59 (1994), 221-239.

[3] J. Bergh, V. I. BurenKov And L. E. Persson, On some sharp reversed Hölder and Hardy type inequalities, Math. Nachr. 169 (1994), 19-29.

[4] V. I. BuRENKOV, On the best constant in Hardy's inequality for $0<p<1$, Trudy Mat. Instit. im V. A. Steklova 194 (1992), 58-62(in Russian).

[5] R. J. BuSHELl AND W. OKRASINSKI, Volterra equations with convolution kernel, J. London Math. Soc. 41 (1990), 503-510.

[6] A. GARCIA DEL AMO, On reverse Hardy's inequality, Collectanea Math. 44 (1993), 115-123.

[7] F. W. GEHRING, The $L^{p}$ - integrability of the partial derivatives of quasiconformal mapping, Acta Math. 130 (1973),265-277.

[8] G. H. Hardy, J. E. LitTlewood And G. Po'Lya, Inequalities, Cambridge Univ. Press, 1952.

[9] H. HeINIG AND L. MALIGRANDA, Weighted inequalities for monotone and concave functions, Studia Math. 116 (2) (1995), 133-165.

[10] G. G. LORENTZ, Some new functional spaces, Ann. of Math. 51 (1950), 37-55.

[11] W. G. MAZJA, Einbettungssätze für Sobolewsche Raume I, Teubener, Leipzig, 1979.

[12] B. MuCKENHOUPT, Weighted norm inequalities for the Hardy maximal function, Trans. Amer. Math. Soc. 165(1972), 207-226.

[13] J. PeCARIC AND L. E. Persson, On Bergh's inequality for quasi-monotone functions, J. Math. Anal. Appl. 195 (1995), 393-400.

[14] J. PECARIC, I. PERIC AND L. E. PERSSON, A multidimensional integral inequality for monotone functions of several variables, Acta Sci. Math. (Szeged) 62 (1996), 407-412.

[15] J. PECARIC, I. PERIC AND L. E. PERSSON, Integral inequalities for monotone functions, J. Math. Anal. Appl. 215 (1997), 235-251.

[16] J. PeCARIC, I. Peric And L. E. Persson, Sharpness of some integral inequalities, Research report 1998:5, Dept. of Math., Luleå University of Technology, ISSN 1400-4003 (19 pages), (submitted).

[17] E. STEIN AND G. WeISS, Introduction to Fourier Analysis on Euclidean Spaces, Princeton Univ. Press, Princeton, New Jersey, 1971.

[18] W. Walter AND V. WeCKesSer, An integral inequality of convolution type, Aeq. Math. 46 (1993), 212-219. 